\title{
og
}

RESEARCH

\section{A Second-Generation Linkage Map of the Bovine Genome}

\author{
Steven M. Kappes, ${ }^{1,3}$ John W. Keele, ${ }^{1}$ Roger T. Stone, ${ }^{1}$ \\ Royal A. McGraw, ${ }^{2}$ Tad S. Sonstegard, ${ }^{1}$ Timothy P.L. Smith, ${ }^{1}$ \\ Nestor L. Lopez-Corrales, ${ }^{1}$ and Craig W. Beattie ${ }^{1}$
}

${ }^{1}$ U.S. Department of Agriculture (USDA), Agricultural Research Service (ARS), U.S. Meat Animal Research Center, Clay Center, Nebraska 68933-0166; ${ }^{2}$ University of Georgia, College of Veterinary Medicine, Athens, Georgia 30602

We report a bovine linkage map constructed with 1236 polymorphic DNA markers and 14 erythrocyte antigens and serum proteins. The 2990-cM map consists of a sex-specific, X chromosome linkage group and 29 sex-averaged, autosomal linkage groups with an average interval size of $2.5 \mathrm{cM}$. The map contains 627 new markers and 623 previously linked markers, providing a basis for integrating the four published bovine maps. Orientation and chromosomal assignment of all the linkage groups, except BTA20 and BTA22, was provided by 88 markers that were assigned previously to chromosomes. This map provides sufficient marker density for genomic scans of populations segregating quantitative trait loci (QTL) and subsequent implementation of marker-assisted selection (MAS) mating schemes.

[Linkage groups for all 29 autosomes and the $X$ and $Y$ chromosomes are presented at http://www.cshl.org/gr/.]

Livestock genetic linkage maps are developed for identifying regions of the genome that influence economically important traits. Most traits of interest in cattle are quantitative in nature and relate to production efficiency, reproduction, or carcass characteristics. The continuous phenotypic distribution observed in most quantitative traits reflects the joint action of multiple loci and environmental influences that increase the difficulty in identifying genetically superior animals. Identification of quantitative trait loci (QTL) can improve selection accuracy and intensity.

Linkage maps with low marker density have been published for cattle (Barendse et al. 1994; Bishop et al. 1994; Georges et al. 1995; Ma et al. 1996b), swine (Ellegren et al. 1994; Rohrer et al. 1994; Archibald et al. 1995), sheep (Crawford et al. 1995), and goats (Vaiman et al. 1996). Average marker interval exceeds $5 \mathrm{cM}$ in pigs and $10 \mathrm{cM}$ in cattle, sheep, and goats. These maps have been used to identify loci in cattle [horn development (Georges et al. 1993a), weaver disease (Georges et al. 1993b), milk production (Georges et al. 1995), roan

${ }^{3}$ Corresponding author.

E-MAIL kappes@map.marc.usda.gov; FAX (402) 762-4390. coat color (Charlier et al. 1996), muscle hypertrophy (Charlier et al. 1995)]; sheep [fecundity (Montgomery et al. 1994) and muscle hypertrophy (Cockett et al. 1994)]; and pigs [fat and growth traits (Andersson et al. 1994) and disease resistance (Edfors-Lilja et al. 1995)]. Most of these loci have been mapped to $>10-\mathrm{cM}$ intervals or they extend beyond the end of the linkage group. Although marker density is sufficient for detecting most QTL, the current maps lack the resolution required for efficient use of marker-assisted selection (MAS) or fine mapping and positional cloning. A second generation map consisting of 1042 loci and an average interval size of $2.23 \mathrm{cM}$ (Rohrer et al. 1996) improves this situation for pigs, but the average interval of the highest resolution cattle map (Bishop et al. 1994) still exceeds $10 \mathrm{cM}$.

We report a high resolution (average interval $2.5 \mathrm{cM}$ ) bovine linkage map with 1250 polymorphic loci covering $2990 \mathrm{cM}$. Six hundred twenty-three previously linked markers provide a basis for integrating the four published bovine maps (Barendse et al. 1994; Bishop et al. 1994; Georges et al. 1995; Ma et al. 1996b). This map increases the power of detecting QTL and improves the potential resolution of a mapped QTL provided sufficient number of re- 


\section{KAPPES ET AL.}

combinant meioses are available. In addition, this map will augment QTL detection and MAS in sheep and goats because a common set of bovine and ovine markers are found on the ovine, caprine, and current bovine linkage maps (Crawford et al. 1995; Vaiman et al. 1996; M.G. de Gortari, B.A. Freking, A.M. Crawford, S.M. Kappes, R.T. Stone, and C.W. Beattie, in prep.), and marker order is virtually identical between sheep and cattle (S.M. Kappes, M.G. Gortari, B.A. Freking, A.M. Crawford, R.T. Stone, J.W. Keele, K. Dodds, and C.W. Beattie, unpubl.; M.G. de Gortari, B.A. Freking, A.M. Crawford, S.M. Kappes, R.T. Stone, and C.W. Beattie, in prep.).

\section{RESULTS}

A second-generation bovine linkage map was constructed with 1250 loci in 29 sex-averaged, autosomal linkage groups and one female-specific (BTAX) linkage group. The male-specific linkage group (BTAY) includes the pseudoautosomal region and two (BM861 and INRA189) Y chromosome-specific markers. The BTA1 linkage group is presented in Figure 1, and all linkage groups are presented at the Genome Research Web site (http://www.cshl.org/gr/). Each linkage group is aligned next to the R-banded karyotype (ISCNDA 1990) of its respective chromosomes. All linkage groups, except for BTA20 and BTA22, are anchored and oriented to the chromosome with 88 physically assigned, polymorphic markers. The orientation of the BTA17 linkage group is supported by physical assignment of the $\gamma$-fibrinogen (FGG) gene on the Barendse et al. (1994) map. References for each physical assignment are presented in Table 1 . The BTA20 linkage group is indirectly anchored by the previous assignment of AGLA29 (Georges and Massey 1992) to synteny group U20b. The MAP1B (referenced in Barendse et al. 1994) gene was used to assign U20b to BTA20. The BTA22 linkage group is also indirectly anchored by the previous assignment of INRA026 (Vaiman et al. 1994a), CSSM006 (Moore et al. 1994) and HUJI75 (Shalom et al. 1994) to synteny group U12. The lactoferrin gene was used to assign U12 to BTA22 (Schwerin et al. 1994). The physical assignment and linkage group nomenclature for BTA25 and BTA29 (Barendse et al. 1994; Bishop et al. 1994; Ma et al. 1996b) have been interchanged according to the recommendation of Popescu et al. (1996) to eliminate the inconsistency identified between linkage group nomenclature and the traditional (1:29) Robertsonian translocation (Eggen et al. 1994; Schmutz et al. 1996).

Clone and primer sequences of all available

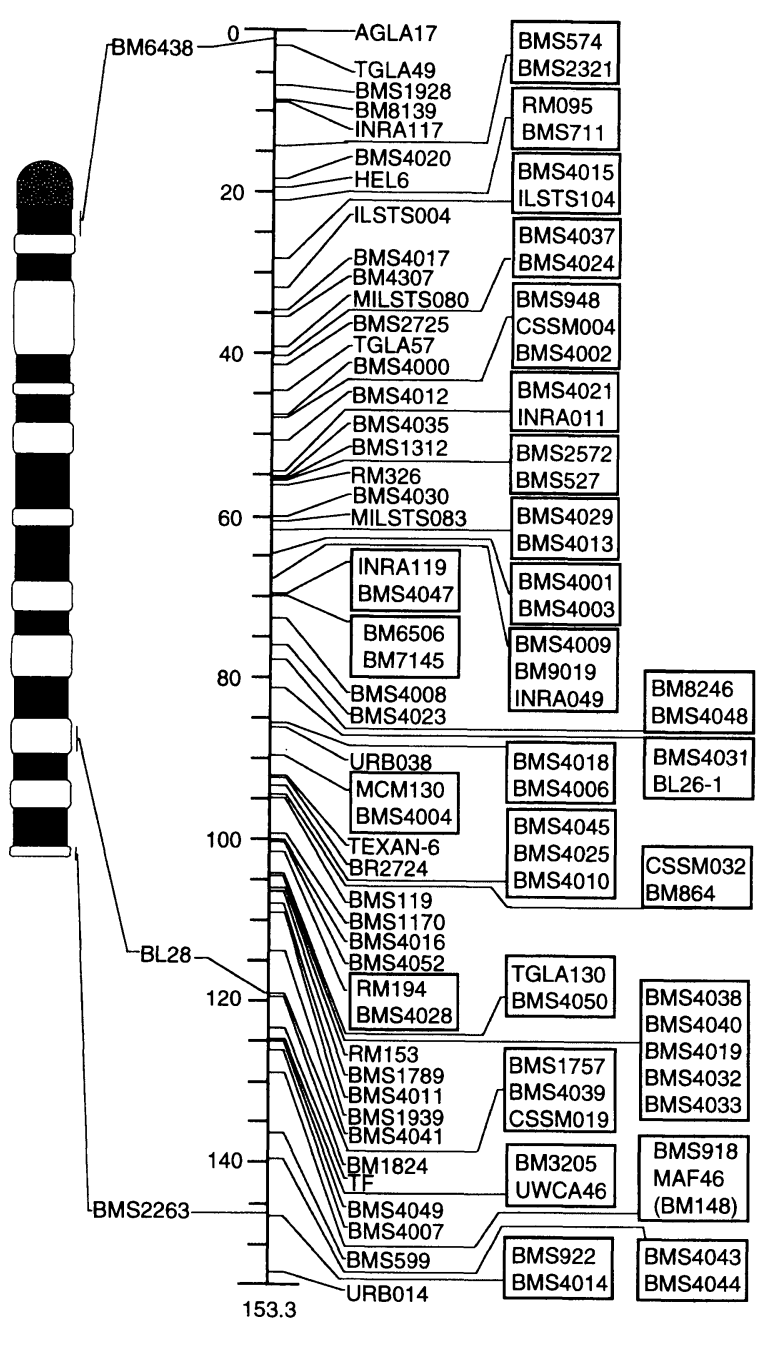

BTA1

Figure 1 Linkage group for bovine chromosome one. The linkage group is oriented next to the Rbanded karyotype (ISCNDA 1990) of the chromosome and labeled below for Bos taurus (BTA). Linkage groups for all 29 autosomes and the $X$ and $Y$ chromosomes are presented at the Genome Research web site (http:// www.cshl.org/gr/). BTA1 is shown here. Markers with physical assignments are at left; their assignments (Table 1) are represented on the R-banded chromosome. Markers in parenthesis (see Web site) are a second set of primers for the same microsatellite as the marker above. No recombination events were detected between markers within a box; therefore, the order in which they are presented is arbitrary. In general, marker order in intervals $<5 \mathrm{cM}$ should be considered tentative as their statistical support was often less than a lod score of 3.0.

markers were compared to identify duplicate markers for the same microsatellite. Seventeen markers (markers in parenthesis in Fig. 1 on Web site) were identified as duplicates, consistent with the pre- 
dicted number of duplications reported by Stone et al. (1995). Occasionally, a set of primer pairs amplified more than one polymorphic locus. The primer pair for BMS4049 amplified a BTA1 (BMS4049) and BTA6 (BMSB4049) locus, and primers for BM9248 amplified a BTA13 (BM9248), BTA12 (BMA9248), and BTA2 (BMB9248) locus. Only six (6/1256, 0.5\%) unlinked markers (10-89 informative meioses) exist in the data set, including the erythrocyte antigen EAJ. No significant twopoint linkages were detected for EAJ (21 informative meioses), although Ma et al. (1996b) reported the linkage of EAJ to the end of their chromosome 11 linkage group. When the lod score criteria was relaxed to 2.0, a two-point linkage was detected between EAJ and HEL13 $(\theta=0.08$; $Z=2.08$ ), consistent with Ma et al. (1996b). Fiftyfive of the linked markers, including erythrocyte antigens and serum proteins, are associated with genes (Table 2). References for each marker are summarized in Table 3 and on the World Wide Web at http://sol.marc.usda.gov/.

Linkage group length and marker density are summarized in Table 4 . The longest (BTA1, 153.3 cM; BTAX, $150.5 \mathrm{cM}$ ) and shortest (BTA28, $52.4 \mathrm{cM}$ ) linkage groups were anchored to the longest and shortest chromosomes, respectively, as reported by Popescu et al. (1996). Linkage groups for larger chromosomes (BTA1-10 and X) tended to be shorter than the predicted length, whereas linkage groups for the smaller chromosomes (BTA15-BTA29) are longer than expected, assuming equal coverage of all chromosomes. The tendency of lower recombination rates on longer chromosomes compared to shorter chromosomes is consistent with recombination rates of yeast chromosomes of different lengths (Kaback et al. 1992), long and short chromosome arms in humans (Morton 1991), and porcine chromosomes (Rohrer et al. 1996).

The number of loci per linkage group was evaluated to determine whether microsatellites are randomly distributed across the bovine genome. BTA1, BTA6, BTA23, BTA25, and X linkage groups contain nonrandomly generated microsatellite markers

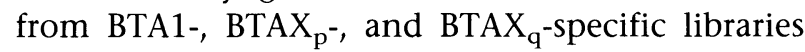
(Ponce de León et al. 1996; Sonstegard et al. $1997 a, b)$ that were excluded from the evaluation. The observed number of loci per linkage group was compared to the expected number, as determined by simulation (100,000 replications) using estimates of chromosome length reported by Popescu et al. (1996). Loci number per linkage group was between the 2.5 and 97.5 percentile for all of the linkage groups except BTA11 and BTAX. The number of loci for BTA11 (68) was eight loci above the $97.5 \%$ level, and BTX (48) was one locus below the $2.5 \%$ level. Deviation from the expected number of loci could have been caused by nonrandom selection of published markers during later stages of map development. Published markers were selectively added to the map if they were linked to marker-deficient regions or had been assigned physically. The lower number of loci on the BTAX linkage group was expected, as some markers were developed from male genomic libraries.

Marker heterozygosity was determined with all (polymorphic and monomorphic) microsatellite markers genotyped on the parents of the USDA Meat Animal Research Center (MARC) reference population (Bishop et al. 1994). The number of microsatellites genotyped per parent ranged from 1372 to 1423 markers. Average marker heterozygosity was $40.2,42.5,59.0$, and $76.0 \%$ for linebred Bos taurus $(n=1)$, purebred $B$. taurus $(n=13), \mathrm{F}_{1} B$. taurus $(n=10)$, and $\mathrm{F}_{1}$ Bos indicus/B. taurus $(n=4)$ parents, respectively. Linked autosomal markers averaged 223 informative meioses from a potential of 412 informative meioses, whereas X-linked markers averaged 85 female informative meioses from a potential of 203 female informative meioses.

A relative scale (1-5) indicating "ease of scoring," was implemented for the last 802 markers genotyped to identify markers suitable for genomic scans in QTL studies. This score is accessible via the World Wide Web at http://sol.marc.usda.gov/. Eighty-five percent (683) and 7\% (59) were classified as primary (score 1 and 2 ) and secondary (score 3 ) markers, respectively. The remaining $7 \%$ are difficult to score (score 4 and 5) and should only be used when both parents can be genotyped with progeny or to identify large genomic clones that contain additional polymorphisms that are easier to score.

Although two detected recombination events within a small interval $(<20 \mathrm{cM})$ generally indicate genotyping errors, some double recombination events are real. Double recombination events were considered actual occurrences after the genotypes causing the double crossovers were validated with a second PCR reaction. Some double recombination events are also documented by more than one marker genotype supporting each crossover event. The number of detected double crossovers within 20-cM intervals per chromosome (Table 4 ) is dependent on the number of markers and the marker density of the chromosome. Although the linkage groups for BTA2 and BTA11 are similar in length (120 and $129 \mathrm{cM})$ and marker density (1.9 average interval size), 8 and 60 double crossovers were detected in the two linkage groups. The higher num- 


\begin{tabular}{|c|c|c|}
\hline Marker & Physical location & Reference \\
\hline BM6438 & $1 q 1.2$ & Sonstegard et al. (1997b) \\
\hline BL28 & $1 \mathrm{q} 4.2$ & Grosz et al. (1997) \\
\hline BMS2263 & $1 \mathrm{q} 4.6$ & Sonstegard et al. (1997b) \\
\hline IDVGA-64 & $2 \mathrm{q} 4.4$ & Mezzelani et al. (1995) \\
\hline IDVGA-37 & $2 \mathrm{q} 4.5$ & Mezzelani et al. (1995) \\
\hline IDVGA-2 & $2 q 4.5$ & Mezzelani et al. (1995) \\
\hline BL41 & $3 q 2.1$ & Grosz et al. (1997) \\
\hline IDVGA-53 & $3 q 2.1$ & Mezzelani et al. (1995) \\
\hline IDVGA-35 & $3 q 3.5$ & Mezzelani et al. (1995) \\
\hline IDVGA-27 & $3 q 3.7$ & Mezzelani et al. (1995) \\
\hline BMC1410 & $4 q 1.3-1.4$ & Solinas-Toldo et al. (1995) \\
\hline IDVGA-51 & $4 q^{3} .1(6 q 3.1)^{a}$ & Mezzelani et al. (1995) \\
\hline BL1121 & $4 q 3.2-3.3$ & Smith et al. (1997) \\
\hline BL37 & $5 q 2.2$ & Grosz et al. (1997) \\
\hline BMC1009 & $5 q 2.3$ & Hawkins et al. (1995) \\
\hline ETH 10 & $5 q 2.5$ & Solinas-Toldo et al. (1993) \\
\hline ETH 2 & $5 q 3.5$ & Solinas-Toldo et al. (1993) \\
\hline IDVGA-9 & $5 q 3.5$ & Mezzelani et al. (1995) \\
\hline CSN3, CSN1S1 & $6 q 2.6-3.3$ & $\begin{array}{l}\text { Threadgill and Womack (1990); } \\
\text { Solinas-Toldo et al. (1995) }\end{array}$ \\
\hline ETH8 & $6 q 3.5$ & Solinas-Toldo et al. (1993) \\
\hline BL1038 & $6 q 3.5-3.6$ & Smith et al. (1997) \\
\hline BL5 & $7 q 1.4$ & Grosz et al. (1997) \\
\hline IL4 & $7 q 1.5-2.1$ & Buitkamp et al. (1995) \\
\hline RASA & 7q2.4-qter & Eggen et al. (1992b) \\
\hline BL1043 & $7 q 28$ & Smith et al. (1997) \\
\hline IDVGA-11 & $8 q 1.4$ & Mezzelani et al. (1995) \\
\hline IDVGA-52 & $8 q 2.3$ & Mezzelani et al. (1995) \\
\hline CSSM025 & $9 q 1.7-1.9$ & Johnson et al. (1995) \\
\hline BMC701 & $9 q 2.2$ & Hawkins et al. (1995) \\
\hline INRA144 & $9 q 2.5$ & Eggen et al. (1992a) \\
\hline BL1134 & $10 q 3.5-3.6$ & Smith et al. (1997) \\
\hline INRA177 & $11 \mathrm{q} 1.6$ & Vaiman et al. (1994b) \\
\hline IDVGA-3 & $11 \mathrm{q} 2.3$ & Mezzelani et al. (1995) \\
\hline LGB & $11 \mathrm{q} 2.8$ & Hayes and Petit (1993) \\
\hline IDVGA-57 & $12 q 1.3$ & Mezzelani et al. (1995) \\
\hline IDVGA-41 & $12 \mathrm{q} 1.5$ & Mezzelani et al. (1995) \\
\hline BMC1222 & $13 q 1.2-1.3$ & Hawkins et al. (1995) \\
\hline ETH7 & $13 q 2.1-2.2$ & Solinas-Tolda et al. (1993) \\
\hline BL42 & $13 q 2.2$ & Grosz et al. (1997) \\
\hline TG & $14 \mathrm{q} 1.2-1.6$ & Threadgill and Womack (1990) \\
\hline BL1036 & $14 q 2.3-2.4$ & Smith et al. (1997) \\
\hline PTH & $15 q 2.2-2.7$ & Fries et al. (1988) \\
\hline HBB & $15 q 2.2-2.7$ & Fries et al. (1988) \\
\hline FSHB & 15q2.4-qter & Hediger et al. (1991) \\
\hline IDVGA-10 & $15 q 2.5$ & Mezzelani et al. (1995) \\
\hline IDVGA-32 & $15 q 2.5$ & Mezzelani et al. (1995) \\
\hline IDVGA-68 & $16 q 1.6$ & Mezzelani et al. (1995) \\
\hline IDVGA-49 & $16 q 1.7$ & Mezzelani et al. (1995) \\
\hline IDVGA-26 & $16 q 2.1$ & Mezzelani et al. (1995) \\
\hline IDVGA-69 & $16 \mathrm{q} 2.1$ & Mezzelani et al. (1995) \\
\hline ETH11 & $16 q 2.1$ & Solinas-Toldo et al. (1993) \\
\hline IDVGA-40 & $17 q 2.3$ & Mezzelani et al. (1995) \\
\hline IDVGA-31 & $18 \mathrm{q} 1.2-1.3$ & Mezzelani et al. (1995) \\
\hline IDVGA-55 & 18q2.4-dist & Mezzelani et al. (1995) \\
\hline
\end{tabular}




\begin{tabular}{|c|c|c|}
\hline Marker & Physical location & Reference \\
\hline IDVGA-46 & $19 q 1.6$ & Mezzelani et al. (1995) \\
\hline KRT10 & $19 q 1.6$ & Fries et al. (1991) \\
\hline ETH12 & $19 q 1.7$ & Solinas-Toldo, et al. (1993) \\
\hline СIOBT34 & $19 q 2.1$ & Olsaker et al. (1996) \\
\hline IDVGA-48 & $19 q 2.1$ & Mezzelani et al. (1995) \\
\hline IDVGA-44 & $19 q 2.2$ & Mezzelani et al. (1995) \\
\hline ETH3 & $19 q 2.3$ & Solinas-Toldo, et al. (1993) \\
\hline IDVGA-45 & $21 q 1.5$ & Mezzelani et al. (1995) \\
\hline UWCA4 & $21 q 1.7$ & Sun et al. (1993) \\
\hline IDVGA-30 & $21 \mathrm{q} 2.3$ & Mezzelani et al. (1995) \\
\hline IDVGA-39 & 21q2.3-prox & Mezzelani et al. (1995) \\
\hline FAS & $26 q 1.3$ & Yoo et al. (1996) \\
\hline IDVGA-59 & $26 \mathrm{q} 2.2$ & Mezzelani et al. (1995) \\
\hline BM203 & $26 q 2.3$ & Masabanda et al. (1996) \\
\hline IDVGA-29 & $28 q 1.3$ & Mezzelani et al. (1995) \\
\hline BMC1002 & $28 q 1.4$ & Hawkins et al. (1995) \\
\hline IDVGA-43 & $28 q 1.7$ & Mezzelani et al. (1995) \\
\hline IDVGA-8 & $28 q 1.8-1.9$ & Mezzelani et al. (1995) \\
\hline BMC8012 & $29 q 1.5(25 q 1.5)^{b}$ & Hawkins et al. (1995) \\
\hline BMC 3224 & $29 q 1.8-1.9(25 q 2.3-2.4)^{b}$ & Hawkins et al. (1995) \\
\hline BMC1206 & $29 q 1.9(25 q 2.4)^{b}$ & Hawkins et al. (1995) \\
\hline IDVGA-7 & $29 q 1.9(25 q 2.4)^{b}$ & $\begin{array}{l}\text { Mezzelani et al. (1995); } \\
\text { Eggen et al. (1994) }\end{array}$ \\
\hline BMS631 & Xp2.4 & Sonstegard et al. (1997a) \\
\hline BL1098 & Xp1.4 & Smith et al. (1997) \\
\hline XBM7 & Xp1.1 & Sonstegard et al. (1997a) \\
\hline XBM111 & $\mathrm{Xq} 1.1$ & Sonstegard et al. (1997a) \\
\hline BM4604 & $X q 2.6-3.1$ & Yeh et al. (1996) \\
\hline BMC6021 & $X q 2.7$ & Sonstegard et al. (1997a) \\
\hline INRA030 & $\mathrm{Xq} 4.32$ & $\begin{array}{l}\text { Ponce de Leon et al. (1996); } \\
\text { Yeh et al. (1996) }\end{array}$ \\
\hline UWCA1 & $23 q 1.4-1.5$ & Sun et al. (1993) \\
\hline HSP70-1 & $23 q 2.2$ & Gallagher et al. 1993 \\
\hline BL6-1 & $24 q^{1} .2$ & Grosz et al. (1997) \\
\hline BMC4216 & $25 q 1.3(29 q 1.3)^{b}$ & Hawkins et al. (1995) \\
\hline
\end{tabular}

ber of double crossovers detected in the BTA11 linkage group probably reflects genotyping errors. The total number of double crossovers (680) within 20cM intervals is $\sim 10$ times the number (66) reported for swine by Rohrer et al. (1996) but significantly less than a simulated estimate (1033 double crossovers) based on 10,000 replications with no crossover interference and a similar number of genotypes as the current map (1250 linked markers and 185 progeny). The higher number of double crossovers in the bovine map than the porcine map is partially explained by a threefold larger bovine data set (313,000 vs. $\sim 100,000$ genotypes), but the presence of a larger number of genotyping errors in the bovine dataset cannot be discounted.

Five $(0.002 \% ; 5 / 313,000)$ non-Mendelian inheritance events were detected that could only be explained by a mutation. This mutation rate is less than the dinucleotide repeat mutation rate reported for humans (4.5 $\times 10^{-4}$; Zahn and Kwiatkowski 1995). It is likely that additional dinucleotide repeat mutations were not detected because they appear to be a genotyping error. 


\section{Table 2. Locus Designation of Markers Associated with Coding Sequences}

\begin{tabular}{|c|c|c|}
\hline Marker name & Chr. & Gene name \\
\hline TF & 1 & transferrin \\
\hline ALPI & 2 & intestinal alkaline phosphatase \\
\hline EAL & 3 & $\begin{array}{l}\text { erythrocyte antigen } L \\
\text { Fc fragment of laC. low affinity }\end{array}$ \\
\hline FCGR2 & 3 & receptor II \\
\hline G-CSFR & 3 & colony-stimulating factor receptor \\
\hline OB & 4 & leptin \\
\hline L18952 & 4 & T-cell receptor, V-region \\
\hline MYF-5 & 5 & myogenic factor 5 \\
\hline BMC1009a & 5 & KRT, Keratin genes \\
\hline IGF-1 & 5 & insulin-like growth factor I \\
\hline CSN3 & 6 & $\kappa$-casein \\
\hline CSN1S1 & 6 & $\alpha_{s 1}$-casein \\
\hline ALB & 6 & albumin \\
\hline GC & 6 & vitamin D-binding protein \\
\hline IL4 & 7 & $\begin{array}{l}\text { interleukin- } 4 \\
\text { RAS p21 protein activator }\end{array}$ \\
\hline RASA & 7 & (GTPase activating protein) \\
\hline CALPASTAT & 7 & calpastatin \\
\hline BRN & 10 & brain ribonuclease \\
\hline EAZ & 10 & erythrocyte antigen $Z$ \\
\hline IL-R1 & 11 & interleukin receptor, type I \\
\hline IL-R2 & 11 & interleukin receptor, type II \\
\hline LGB & 11 & lactoglobin, $\beta$ \\
\hline EAB & 12 & erythrocyte antigen B \\
\hline TG & 14 & thyroglobulin \\
\hline CA2 & 14 & $\begin{array}{l}\text { carbonic anhydrase II } \\
\text { calmodulin-independent }\end{array}$ \\
\hline ADCY2 & 15 & adenylate cyclase \\
\hline EAA & 15 & erythrocyte antigen $\mathrm{A}$ \\
\hline PTH & 15 & parathyroid hormone \\
\hline HBB & 15 & hemoglobin, $\beta$ \\
\hline РОТСHА & 15 & $\begin{array}{l}\text { potassium channel protein } \\
\text { follicle-stimulating hormone, }\end{array}$ \\
\hline FSHB & 15 & $\beta$ subunit \\
\hline EAR' $^{\prime}$ & 16 & erythrocyte antigen $\mathrm{R}^{\prime}$ \\
\hline EAC & 18 & erythrocyte antigen $C$ \\
\hline KRT10 & 19 & cytokeratin class I gene cluster \\
\hline PTF2 & 19 & post-transferrin factor 2 \\
\hline GFAB & 19 & glial fibrillary acidic protein \\
\hline $\mathrm{GH}$ & 19 & growth hormone \\
\hline MAP2C & 19 & microtubule-associated protein 2 \\
\hline $\mathrm{EAT}^{\prime}$ & 19 & erythrocyte antigen $T^{\prime}$ \\
\hline ANPRC & 20 & atrial-natriuretic peptide $C$ receptor \\
\hline EAS & 21 & erythrocyte antigen $\mathrm{S}$ \\
\hline $\mathrm{HMH} 1 \mathrm{R}$ & 22 & $\begin{array}{l}\text { histamine receptor, } \mathrm{H} 1 \text { subclass } \\
\text { major histocompatibility }\end{array}$ \\
\hline BOLA-DIB & 23 & complex, DI $\beta$ \\
\hline VEGF & 23 & vascular endothelial growth factor \\
\hline EAM & 23 & erythrocyte antigen $\mathrm{M}$ \\
\hline HSP70-1 & 23 & 70-kD heat-shock protein \\
\hline BOLA-DRB1 & 23 & $\begin{array}{l}\text { major histocompatibility complex, } \\
\text { class II, DR } \beta I\end{array}$ \\
\hline
\end{tabular}




\begin{tabular}{|c|c|c|}
\hline Marker name & Chr. & Gene name \\
\hline BOLA-DRB2 & 23 & $\begin{array}{l}\text { major histocompatibility complex, } \\
\text { class II DR } \beta \text { II }\end{array}$ \\
\hline CYP21 & 23 & $\begin{array}{l}\text { cytochrome P450, subfamily XXI } \\
\text { (steroid } 21 \text {-hydroxylase) }\end{array}$ \\
\hline L29386 & 23 & $\begin{array}{l}\text { major histocompatibility complex, } \\
\text { class } 1\end{array}$ \\
\hline PRL & 23 & prolactin \\
\hline PAI & 25 & $\begin{array}{l}\text { type- } 1 \text { plasminogen activator } \\
\text { inhibitor }\end{array}$ \\
\hline FAS & 26 & Fas/APO-1 \\
\hline RBP3 & 28 & $\begin{array}{l}\text { retinol-binding protein } 3, \\
\text { interstitial }\end{array}$ \\
\hline OCAM & 29 & $\begin{array}{l}\text { opioid-binding and cell adhesion } \\
\text { molecule }\end{array}$ \\
\hline
\end{tabular}

aSequence homology to bovine keratin genes as determined by Vaiman et al. (1996).

\section{DISCUSSION}

This second-generation bovine linkage map represents a fourfold increase in map resolution $(2.5 \mathrm{cM}$ average interval) over the previous highest resolution bovine map (10.6 cM; Bishop et al. 1994). Six hundred twenty-seven new markers were linked to 623 markers with previous linkage information to provide a basis for integrating the four published bovine maps. In addition to the 313 markers in our previous map (Bishop et al. 1994), the current map contains 70\% (119/171), 78\% (211/269), and 47\% $(75 / 159)$ of the markers reported by Barendse et al. (1994), Ma et al. (1996b), and Georges et al. (1995), respectively. This map can be utilized easily in many different resource populations at different locations because $98.6 \%(1233 / 1250)$ of the markers are PCR based, with all but two being microsatellites.

Linkage group distances were compared with common markers between the current map and previously published maps to evaluate error detection capabilities with a higher marker density map. The 24\% (Barendse et al. 1994; 1677/1348 cM) and 13\% (Bishop et al. 1994; 2463/2178 cM) smaller size of the current map compared with the two previous sex-averaged maps was expected, as error detection improves as marker density increases (Lincoln and Lander 1992). The current map is $6 \%$ smaller (Ma et al. 1996b; 1730/1625 cM) and 5\% larger (Georges et al. 1995; 971/1017 cM) than the two male maps. Male maps are expected to be shorter than a comparable sex-averaged map because of sex-specific differences in recombination rates (Davisson et al. 1989).
Although sex-specific differences in recombination rates have been reported for cattle (Beever et al. 1996), pigs (Archibald et al. 1995), and humans (Dracopoli et al. 1991), the sex-specific difference of the current map (female, $2879 \mathrm{cM}$; male, $2808 \mathrm{cM}$ ) is considerably smaller than the 1.9:1 (female/male) ratio reported for humans by Matise et al. (1994). Apparent differences in sex-specific map lengths can result from inadequate sex-specific coinformative meioses. Initial analysis of the current data set (185 progeny) indicated a $2907-\mathrm{cM}$ male map and a 2879-cM female map. Closer examination of the data revealed a $100-\mathrm{cM}$ interval between AGLA17 and BM6438 (BTA1) in the male map, whereas only a 1.3-cM interval was observed in the female map. Because the 100-cM interval was supported by only three male informative meioses for AGLA17 and the 1.3-cM female interval was supported by 75 informative meioses, the $100-\mathrm{cM}$ male interval was adjusted to $1.3 \mathrm{cM}(2907-98.7=2808 \mathrm{cM})$. The small difference $(71 \mathrm{cM})$ in the current sex-specific maps does not preclude sex-specific differences in certain regions of the genome.

As linkage maps continue to develop and additional markers improve the resolving power of the map, genotyping errors also accumulate, introducing spurious recombination events that inflate the linkage group length. As the error rate increases, the statistical support for correct marker order decreases (Ott 1977; Buetow 1991; Morton 1991). The ability to detect genotyping errors improves as marker density increases (Buetow 1991), but the adverse effects of a given error rate also increase with higher marker 


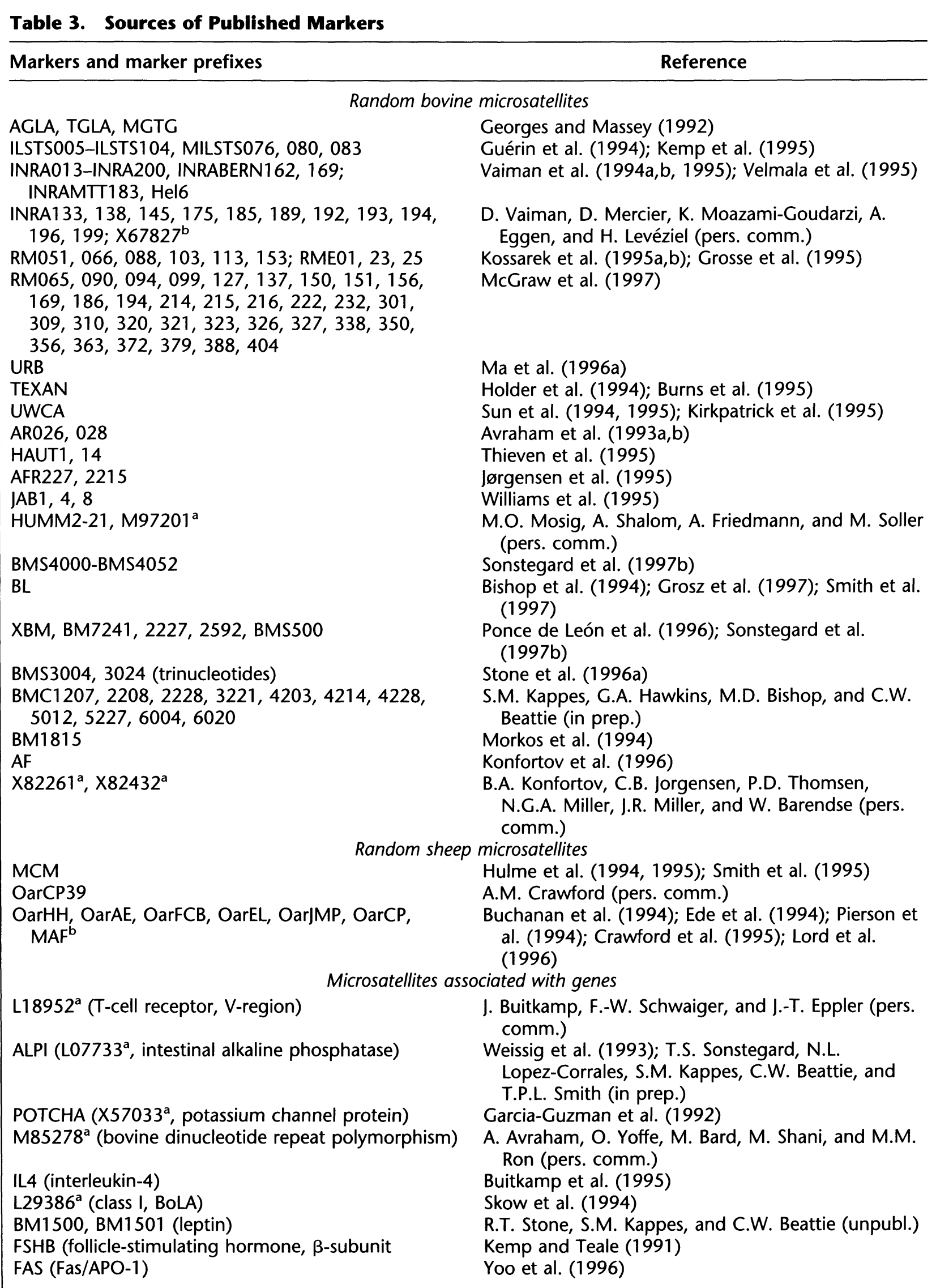


Table 3. (Continued)

\begin{tabular}{ll}
\hline Markers and marker prefixes & \multicolumn{1}{c}{ Reference } \\
\hline \multicolumn{1}{c}{ Restriction fragment length polymorphisms } \\
IL1-R1, IL1-R2 (interleukin receptor, type I, II) & Yoo et al.(1994) \\
G-CSFR (colony-stimulating factor receptor) & Yoo et al. (1995) \\
DIB (BoLA, DIB) & Morkos et al. (1994) \\
OBS (leptin) & Stone et al. (1996b) \\
TC (thyroglobulin) & Daskalchuk and Schmutz (1997) \\
CSN1S1 ( $\alpha_{s 1}$-Casein) & David and Deutch (1992) \\
\hline Markers not listed in Tables 1 and 3 have been referenced in one of the following: Barendse et al. (1994); Bishop et al. (1994); Moore \\
et al. (1994); Stone et al. (1995, 1997). \\
aCenBank accession number. \\
bln original publications, some of the sheep markers were lacking the Oar prefix.
\end{tabular}

density (Lincoln and Lander 1992). Consequently, intensive correction of genotyping errors in dense maps results in large reductions of map length and improved marker order. We considered genotypes causing two or more recombination events in a small chromosomal region $(<20 \mathrm{cM})$ as potential genotyping errors. A second PCR reaction was genotyped for the potential errors, correcting $0.33 \%$ of the total genotypes $(1026 / 313,000)$ and reducing total map length by $23 \%(3680 / 2990 \mathrm{cM})$. Genotypes validated by a second PCR reaction and still causing unlikely recombination events were maintained in the data set because it may be indicative of other genotyping errors or an incorrect marker order.

Estimates of bovine genome size range from 3000 (Fries and Ruddle 1986) to $2820 \mathrm{cM}$ (Barendse et al. 1993). The ratio of chiasmata to genome length (2 chiasmata/cell = 1 Morgan; 2:1) used to estimate genome length for bulls presents an unlikely cow genome size $(1.8 \mathrm{M})$; therefore, the $1.135: 1$ ratio observed in women was used for cows (Barendse et al. 1994). Although the current map (2990 cM) is similar to the Fries and Ruddle (1986) estimate and slightly larger than the Barendse et al. (1993) estimate, it is likely that our data set still contains undetected genotyping errors and the map does not represent complete coverage of all 30 chromosomes. A more robust estimate of genome size and coverage can be made when polymorphic markers from the ends of linkage groups are physically assigned to chromosomes.

The fourfold increase in marker density of the current map allows for an efficient genome-wide QTL search, but additional markers will be needed in regions flanking QTL for efficient MAS. Marker density in regions containing QTL is likely to be one of the limiting factors in resolving QTL location and efficiency of MAS because $<60 \%$ of the markers on the current map are informative within a $F_{1} B$. taurus animal and $14 \%(177 / 1220)$ of the intervals are greater than the 10-cM maximum suggested by Ott and Donis-Keller (1994).

Unfortunately, livestock mapping resources are currently targeted toward QTL detection, and additional large-scale development of random markers appears to be unlikely in the near future. Several strategies exist for generating additional markers for specific regions of the genome containing QTL. These include microdissected, microcloned libraries (Ponce de León et al. 1996; Sonstegard et al. 1997a,b) and identification of YAC clones (Smith et al. 1997) containing the closest flanking markers to the QTL. Additional microsatellites can be identified within a YAC clone (Lench et al. 1996) for haplotyping to increase the polymorphic content of a marker locus to the extent that it is informative in almost every animal. Comparative mapping information from human and mouse genome mapping efforts can also improve QTL mapping efficiency by providing candidate genes based on location and function. Comparative mapping within Bovidae families can improve the respective linkage maps and QTL detection because cattle and sheep microsatellites have been used reciprocally in cattle, sheep, and goat maps (Barendse et al. 1994; Bishop et al. 1994; Crawford et al. 1995; Vaiman et al. 1996; M.G. de Gortari, B.A. Freking, A.M. Crawford, S.M. Kappes, R.T. Stone, and C.W. Beattie, in prep.). Marker order appears virtually identical between sheep and cattle and very similar between goat and the other two species (Vaiman et al. 1996; S.M. Kappes, M.G. de Gortari, B.A. Freking, A.M. Crawford, R.T. Stone, J.W. Keele, K. Dodds, and C.W. 
KAPPES ET AL.

\begin{tabular}{|c|c|c|c|c|c|c|}
\hline Chromosome & No. of loci ${ }^{\mathrm{a}}$ & $\begin{array}{c}\text { Length }^{\mathbf{b}} \\
(\mathrm{cm})\end{array}$ & $\begin{array}{l}\text { Avg. interval } \\
(\mathrm{cm})\end{array}$ & $\begin{array}{c}\text { No. of double } \\
\text { crossovers }^{c}\end{array}$ & $\begin{array}{l}\text { Percent of } \\
\text { genome }^{d}\end{array}$ & $\begin{array}{c}\text { Expected } \\
\text { length }(\mathrm{cm})^{\mathrm{e}}\end{array}$ \\
\hline 1 & $102 / 58$ & 153 & $1.5 / 2.6$ & 43 & 5.87 & $176(-13)$ \\
\hline 2 & 62 & 120 & 1.9 & 8 & 5.12 & $154(-22)$ \\
\hline 3 & 64 & 127 & 2.0 & 34 & 4.71 & $141(-10)$ \\
\hline 4 & 46 & 108 & 2.3 & 32 & 4.67 & $140(-23)$ \\
\hline 5 & 45 & 133 & 3.0 & 58 & 4.48 & $134(-1)$ \\
\hline 6 & $50 / 49$ & 126 & $2.5 / 2.6$ & 29 & 4.33 & $130(-3)$ \\
\hline 7 & 41 & 137 & 3.4 & 31 & 4.18 & $125(+9)$ \\
\hline 8 & 38 & 124 & 3.2 & 32 & 4.13 & $124(0)$ \\
\hline 9 & 52 & 108 & 2.1 & 22 & 3.86 & $116(-6)$ \\
\hline 10 & 47 & 105 & 2.2 & 23 & 3.67 & $110(-5)$ \\
\hline 11 & 68 & 129 & 1.9 & 60 & 3.94 & $118(+9)$ \\
\hline 12 & 35 & 105 & 3.0 & 24 & 3.29 & $99(+6)$ \\
\hline 13 & 34 & 87 & 2.6 & 7 & 3.09 & $93(-6)$ \\
\hline 14 & 35 & 89 & 2.5 & 28 & 3.15 & $95(-6)$ \\
\hline 15 & 39 & 109 & 2.8 & 49 & 3.11 & $93(+17)$ \\
\hline 16 & 38 & 94 & 2.5 & 22 & 3.07 & $92(+2)$ \\
\hline 17 & 31 & 99 & 3.2 & 6 & 2.83 & $85(+17)$ \\
\hline 18 & 39 & 81 & 2.1 & 10 & 2.60 & $78(+4)$ \\
\hline 19 & 37 & 100 & 2.7 & 9 & 2.54 & $76(+31)$ \\
\hline 20 & 28 & 75 & 2.7 & 5 & 2.75 & $83(-9)$ \\
\hline 21 & 35 & 94 & 2.7 & 26 & 2.72 & $82(+16)$ \\
\hline 22 & 28 & 79 & 2.8 & 14 & 2.51 & $75(+5)$ \\
\hline 23 & $30 / 29$ & 68 & $2.3 / 2.3$ & 23 & 2.09 & $63(+8)$ \\
\hline 24 & 29 & 61 & 2.1 & 7 & 2.37 & $71(-14)$ \\
\hline $25^{f}$ & $23 / 22$ & 71 & $3.1 / 3.2$ & 9 & 1.99 & $69(+18)$ \\
\hline 26 & 25 & 72 & 2.9 & 20 & 1.96 & $59(+22)$ \\
\hline 27 & 25 & 64 & 2.6 & 20 & 1.83 & $55(+17)$ \\
\hline 28 & 27 & 52 & 1.9 & 8 & 1.73 & $52(+1)$ \\
\hline $29^{f}$ & 32 & 69 & 2.2 & 8 & 1.97 & $59(+17)$ \\
\hline$X$ & $65 / 48$ & 151 & $2.3 / 3.1$ & 16 & 5.45 & $163(-8)$ \\
\hline Total & $1250 / 1186$ & 2990 & 2.4 & 680 & & \\
\hline
\end{tabular}

'The second number does not include 64 markers generated from chromosome 1, Xp, and Xq microdissected libraries (Ponce de León et al. 1996; Sonstegard et al. 1997a,b).

${ }^{b}$ All values are for a sex-averaged map except the $X$ chromosome value, which is a female map length.

'Number of double recombination events detected within 20-cM intervals, including double recombination events supported by more than one genotype.

${ }^{d}$ Estimate of chromosome size relative to total genome was reported by Popescu et al. (1996).

expected length was calculated by multiplying the percent of genome by $3000 \mathrm{cM}$. Numbers in parentheses represent the percent difference between actual and expected (actual/expected).

${ }^{\mathrm{f}}$ The nomenclature for the chromosome 25 and 29 linkage groups has been interchanged to be consistent with Robertsonian 1:29 translocation data (Eggen et al. 1994; Popescu et al. 1996; Schmutz et al. 1996).

Beattie, unpubl.). QTL detected in one species may be useful for understanding the biology of a trait with a similar phenotype in the other two species.

In summary, the current map represents a considerable improvement in bovine map resolution that will enhance QTL detection and subsequent MAS or positional cloning. Additional markers will likely be needed in specific regions of the genome that contain QTL, but strategies are available to increase marker density in those regions. The usefulness of this linkage map extends beyond cattle, to sheep and goats, where it is unlikely that a large number of additional markers will be generated in the near future. 


\section{METHODS}

\section{Data Collection}

Markers were genotyped across the MARC reference population (Bishop et al. 1994). Genomic DNA was obtained from whole blood by the salt extraction method described previously by Miller et al. (1988). Conditions used to amplify specific segments of genomic DNA were consistent with Bishop et al. (1994) while reducing the quantity of DNA per reaction to $50 \mathrm{ng}$. Amplified products were $\left[\alpha-{ }^{32} \mathrm{P}\right] \mathrm{dATP}$ labeled by random incorporation, or one of the primers was end labeled to reduce sub-banding. Primer pairs were occasionally multiplexed when sizes and PCR conditions allowed. Gel electrophoresis and scoring of grandparental, parental, and progeny genotypes were performed essentially according to Bishop et. al. (1994). Genotypes were independently scored twice and discrepancies resolved. All primer sequences were reported previously (Table 2 ).

\section{Data Analyses}

Markers were placed into linkage groups based on two-point lod (>3.0) scores and ordered within the group using multipoint linkage analysis (CRI-MAP v. 2.4; Green et al. 1990). New markers were added to linkage groups with the ALL option by inserting the markers with the largest number of informative meioses first. The FLIPS option was used after inserting three to four markers per linkage group to evaluate local marker order. Two-point linkage information and sheep linkage mapping information (M.G. de Gortari, B.A. Freking, A.M. Crawford, S.M. Kappes, R.T. Stone, and C.W. Beattie, in prep.) were used to determine marker order for markers that inflated the linkage group $>20 \mathrm{cM}$. Linkage groups were periodically rebuilt with the BUILD option by inserting markers in decreasing informative meioses order. After preliminary alignment, the CHROMPIC option was used to identify unlikely double crossovers.

The CHROMPIC option worked well for identifying genotypic errors in progeny but was less effective in identifying parental and grandparental genotypic errors. Family recombination rates were compared to identify potential parental and grandparental genotyping errors. Genotypes causing double crossovers were rescored from a second PCR reaction as advised by Buetow (1991) and entered into an interactive relational database (Keele et el. 1994). The FLIPS option was used subsequent to error corrections to determine marker order with the highest log likelihood.

Linkage groups containing a number of markers with like-heterozygote genotypes for the sire, dam, and progeny (identified as switches in CRI-MAP 2.4) could not be analyzed because of computational requirements. Markers containing a large number $(>20)$ of like-heterozygote genotypes were removed from the initial multipoint analysis to determine marker order of the remaining markers. Markers containing like-heterozygote genotypes were included in the final analysis, but like-heterozygote genotypes of the progeny were removed from families contributing the largest number of computationally demanding genotypes.

Common linkage group distances were calculated from the current map and different published maps (Barendse et al. 1994; Bishop et al. 1994; Georges et al. 1995; Ma et al. 1996b) using the two most external common markers for each linkage group. Linkage groups that did not contain two or more common markers between the current map and a published map were not included in the comparison.

Marker heterozygosity was determined only for parents of the reference mapping population by dividing the number of heterozygous genotypes by the total number of markers genotyped per animal. Heterozygosity values were averaged across animals of similar breed type with each animal weighted equally. The heterozygosity formula of $1-\Sigma\left(P_{i}\right)^{2}$ was not used as 1-13 animals per breed type was not considered sufficient to give a reliable estimate of allele frequency.

\section{ACKNOWLEDGMENTS}

We thank L. Flathman, K. Katzberg, S. Simcox, S. Nejezchleb, and R. Godtel for excellent technical assistance, S. Kluver and L. Yen for manuscript preparation, and the MARC cattle crew for outstanding husbandry. Mention of trade name, proprietary product, or specific equipment does not constitute a guarantee or warranty by the USDA and does not imply approval to the exclusion of other products that may be suitable.

The publication costs of this article were defrayed in part by payment of page charges. This article must therefore be hereby marked "advertisement" in accordance with 18 USC section 1734 solely to indicate this fact.

\section{REFERENCES}

Andersson, L., C.S. Haley, H. Ellegren, S.A. Knott, M. Johansson, K. Andersson, L. Andersson-Eklund, I. Edfors-Lilja, M. Fredholm, I. Hansson, J. Håkansson, and K. Lundström. 1994. Genetic mapping of quantitative trait loci for growth and fatness in pigs. Science 263: 1771-1774.

Archibald, A.L., C.S. Haley, J.F. Brown, S. Couperwhite, H.A. McQueen, D. Nicholson, W. Coppieters, A. Van de Weghe, A. Stratil, A.K. Winterø, M. Fredholm, N.J. Larsen, V.H. Nielsen, D. Milan, N. Woloszyn, A. Robic, M. Dalens, J. Riquet, J. Gellin, J.-C. Caritez, G. Burgaud, L. Ollivier, J.-P. Bidanel, M. Vaiman, C. Renard, H. Geldermann, R. Davoli, D. Ruyter, E.J.M. Verstege, M.A.M. Groenen, W. Davies, B. Heyheim, A. Keiserud, L. Andersson, H. Ellegren, M. Johansson, L. Marklund, J.R. Miller, D.V. Anderson Dear, E. Signer, A.J. Jeffreys, C. Moran, P. Le Tissier Muladno, M.F. Rothschild, C.K. Tuggle, D. Vaske, J. Helm, H.-C. Liu, A. Rahman, T.-P. Yu, R.G. Larson, and C.B. Schmitz. 1995. The PiGMaP consortium linkage map of the pig (Sus scrofa). Mamm. Genome 6: 157-175.

Avraham, A., M. Band, O. Yoffe, M. Shani, and M. Ron. 1993a. Bovine dinucleotide repeat polymorphism at the ARO26 locus. Anim. Genet. 24: 147.

1993b. Bovine dinucleotide repeat polymorphism at the ARO28 locus. Anim. Genet. 24: 147.

Barendse, W., S.M. Armitage, A.M. Ryan, S.M. Moore, D. Clayton, M. Georges, J.E. Womack, and J. Hetzel. 1993. A genetic map of DNA loci on bovine chromosome 1. Genomics 18: 602-608.

Barendse, W., S.M. Armitage, L.M. Kossarek, A. Shalom, B.W. Kirkpatrick, A.M. Ryan, D. Clayton, L. Li, H.L. Neibergs, N. Zhang, W.M. Grosse, J. Weiss, P. Creighton, F. 
KAPPES ET AL.

McCarthy, M. Ron, A.J. Teale, R. Fries, R.A. McGraw, S.S. Moore, M. Georges, M. Soller, J.E. Womack, and D.J.S. Hetzel. 1994. A genetic linkage map of the bovine genome. Nature Genet. 6: 227-235.

Beever, J.E., H.A. Lewin, W. Barendse, L. Andersson, S.M. Armitage, C.W. Beattie, B.M. Burns, S.K. Davis, S.M. Kappes, B.W. Kirkpatrick, R.Z. Ma, R.A. McGraw, R.T. Stone, and J.F. Taylor. 1996. Report of the first workshop on the genetic map of bovine chromosome 23. Anim. Genet. 27: 69-75.

Bishop, M.D., S.M. Kappes, J.W. Keele, R.T. Stone, S.L.F. Sunden, G.A. Hawkins, S.S. Toldo, R. Fries, M.D. Grosz, J. Yoo, and C.W. Beattie. 1994. A genetic linkage map for cattle. Genetics 136: 619-639.

Buchanan, F.C., S.M. Galloway, and A.M. Crawford. 1994. Ovine microsatellites at the OarFCB5, OarFCB19, OarFCB20, OarFCB48, OarFCB129 and OarFCB226 loci. Anim. Genet. 25: 60 .

Buetow, K.H. 1991. Influence of aberrant observations on high-resolution linkage analysis outcomes. Am. J. Hum. Genet. 49: 985-994.

Buitkamp, J., F.-W. Schwaiger, S. Solinas-Toldo, R. Fries, and J.T. Epplen. 1995. The bovine interleukin-4 gene: Genomic organization, localization, and evolution. Mamm. Genome 6: $350-356$

Burns, B.M., J.F. Taylor, K.L. Herring, A.D. Herring, M.T. Holder, J.S. Collins, T.M. Guerra, J.O. Sanders, and S.K. Davis. 1995. Bovine microsatellite mononucleotide and dinucleotide repeat polymorphisms at the TEXAN6, TEXAN7, TEXAN8, TEXAN9 and TEXAN10 loci. Anim. Genet. 26: 129-130.

Charlier, C., W. Coppieters, F. Farnir, L. Grobet, P.L. Leroy, C. Michaux, M. Mni, A. Schwers, P. Vanmanshoven, R. Hanset, and M. Georges. 1995. The $m h$ gene causing double-muscling in cattle maps to bovine Chromosome 2 . Mamm. Genome 6: 788-792.

Charlier, C., B. Denys, J.I. Belanche, W. Coppieters, L. Grobet, M. Mni, J. Womack, R. Hanset, and M. Georges. 1996. Microsatellite mapping of the bovine roan locus: A major determinant of White Heifer Disease. Mamm. Genome 7: 138-142.

Cockett, N.E., S.P. Jackson, T.L. Shay, D. Nielsen, S.S. Moore, M.R. Steele, W. Barendse, R.D. Green, and M. Georges. 1994. Chromosomal localization of the callipyge gene in sheep (Ovis aries) using bovine DNA markers. Proc. Natl. Acad. Sci. 91: 3019-3023.

Crawford, A.M., K.G. Dodds, A.J. Ede, C.A. Pierson, G.W. Montgomery, H.G. Garmonsway, A.E. Beattie, K. Davies, J.F. Maddox, S.M. Kappes, R.T. Stone, T.C. Nguyen, J.M. Penty, E.A. Lord, J.E. Broom, J. Buitkamp, W. Schwaiger, J.T. Epplen, P. Matthew, M.E. Matthews, D.J. Hulme, K.J. Beh, R.A. McGraw, and C.W. Beattie. 1995. An autosomal genetic linkage map of the sheep genome. Genetics 140: 703-724.

Daskalchuk, T.E. and S.M. Schmutz. 1997. Genetic mapping of thyroglobulin on bovine chromosome 14. Mamm. Genome 8: 74-76.

David, V.A. and A.H. Deutch. 1992. Detection of bovine $\alpha_{\mathrm{s} 1}$-casein genomic variants using the allele-specific polymerase chain reaction. Anim. Genet. 23: 425-429.

Davisson, M.T., T.H. Roderick, and D.P. Doolittle. 1989. Recombination percentages and chromosomal assignments. In Genetic variants and strains of the laboratory mouse, 2 nd ed. (ed. M.F. Lyons and A.G. Searle), pp. 432-505. Oxford University Press, Oxford, UK.

Dracopoli, N.C., P. O'Connell, T.I. Elsner, J.-M. Lalouel, R.L. White, K.H. Buetow, and D.Y. Nishimura. 1991. The CEPH consortium linkage map of human chromosome 1. Genomics 9: 686-700.

Ede, A.J., C.A. Peirson, H. Henry, and A.M. Crawford. 1994 Ovine microsatellites at the OarAE64, OarHH22, OarHH56, OarHH62 and OarVH4 loci. Anim. Genet. 25: 51-52.

Edfors-Lilja, I., U. Gustafsson, Y. Duval-Iflah, H. Ellegren, M. Johansson, R.K. Juneja, L. Marklund, and L. Andersson. 1995. The porcine intestinal receptor for Escherichia coli K88ab, K88ac: Regional localization on chromosome 13 and influence of IgG response to the K88 antigen. Anim. Genet. 26: $237-242$.

Eggen, A., I. Bahri-Darwich, D. Mercier, D. Vaiman, and E.P. Cribiu. 1992a. Assignment of bovine synteny group U2 to chromosome 9. Anim. Genet. 25: 183-185.

Eggen, A., S. Solinas Toldo, A.B. Dietz, J.E. Womack, G. Stranzinger, and R. Fries. 1992b. RASA contains a polymorphic microsatellite and maps to bovine syntenic group U22 on chromosome 7q24-qter. Mamm. Genome 3: $559-563$.

Eggen, A., A. Oustry, D. Vaiman, L. Ferreti, R. Fries, and E.P. Cribiu. 1994. Bovine synteny group U7, previously assigned to chromosome 25 in the ISCNDA nomenclature, assigns to R-banded chromosome 29. Hereditas 121: 295-300.

Ellegren, H., B.P. Chowdhary, M. Johansson, L. Marklund, M. Fredholm, I. Gustavsson, and L. Andersson. 1994. A primary linkage map of the porcine genome reveals a low rate of genetic recombination. Genetics 137: 1089-1100.

Fries, F. and F.H. Ruddle. 1986. Gene mapping in domestic animals. In Beltsville Symposium in Agriculture Research: Biotechnology for Solving Agriculture Problems, Vol 10 (ed. J. St. John), pp. 19-37. American Society of Animal Science, Savory, IL.

Fries, R., R. Hediger, and G. Stranzinger. 1988. The loci for parathyroid hormone and beta-globin are closely linked and map to chromosome 15 in cattle. Genomics 3: 302-307.

Fries, R., D.W. Threadgill, R. Heidiger, A. Gunawardana, M. Blessing, J.L. Jorcano, G. Stranzinger, and J.E. Womack. 1991. Mapping of bovine cytokeratin sequences to four different sites on three chromosomes. Cytogenet. Cell Genet. 57: 135-141. 
Gallagher, D.S., M.D. Grosz, J.E. Womack, and L.C. Skow. 1993. Chromosomal localization of HSP7O genes in cattle. Mamm. Genome 4: 388-390.

Garcia-Guzman, M., S. Calvo, V. Cena, and M. Criado. 1992. Molecular cloning and permanent expression in a neuroblastoma cell line of a fast inactivating potassium channel from bovine adrenal medulla. FEBS Lett.

308: 283-289.

Georges, M. and J. Massey. 1992. Polymorphic DNA markers in Bovidae (World Intellectual Property Org., Geneva) World Organization publ. no. 9 2/13102.

Georges, M., R. Drinkwater, T. King, A. Mishra, S.S. Moore, D. Nielsen, L.S. Sargeant, A. Sorensen, M.R. Steele, X. Zhao, J.E. Womack, and J. Hetzel. 1993a. Microsatellite mapping of a gene affecting horn development in Bos taurus. Nature Genet. 4: 206-210.

Georges, M., A.B. Dietz, A. Mishra, D. Nielsen, L.S. Sargeant, A. Sorensen, M.R. Steele, X. Zhao, H. Leipold, J.E. Womack, and M. Lathrop. 1993b. Microsatellite mapping of the gene causing Weaver disease in cattle will allow the study of an associated quantitative trait locus. Proc. Natl. Acad. Sci. 90: $1058-1062$.

Georges, M., D. Nielsen, M. Mackinnon, A. Mishra, R. Okimoto, A.T. Pasquino, L.S. Sargeant, A. Sorensen, M.R. Steele, X. Zhao, J.E. Womack, and I. Hoeschele. 1995. Mapping quantitative trait loci controlling milk production in dairy cattle by exploiting progeny testing. Genetics 139: 907-920.

Green, P., K. Falls, and S.Crooks. 1990. Documentation for CRI-MAP, version 2.4. Washington University School of Medicine, St. Louis, MO.

Grosse, W.M., O. Finlay, L.M. Kossarek, T.G. Clark, and R.A. McGraw. 1995. Five bovine microsatellite markers derived from skeletal muscle cDNA: RME01, RME11, RME23, RME25, and RME33. Anim. Genet. 26: 126-127.

Grosz, M.D., S. Solinas-Toldo, R.T. Stone, S.M. Kappes, R. Fries, and C.W. Beattie. 1997. Chromosomal localization of six bovine microsatellite markers. Anim. Genet. (in press).

Guérin, G., M. Nocart, and S.J. Kemp. 1994. Fifteen new synteny assignments of microsatellites to the bovine genome. Anim. Genet. 25: 179-181.

Hawkins, G.A., S. Solinas-Toldo, M.D. Bishop, S.M. Kappes, R. Fries, and C.W. Beattie. 1995. Physical and linkage mapping of the bovine genome with cosmids. Mamm. Genome 6: 249-254.

Hayes, C.H. and E.J. Petit. 1993. Mapping of the $\beta$-lactoglobulin gene and of an immunoglobulin $\mathrm{M}$ heavy chain-like sequence to homologous cattle, sheep and goat chromosomes. Mamm. Genome 4: 207-210.

Hediger, R., S.E. Johnson, and D.J.S. Hetzel. 1991. Localization of the beta-subunit of follicle stimulating hormone in cattle and sheep by in situ hybridization. Anim. Genet. 22: 237-244.

Holder, D.A., E. Arevalo, M.T. Holder, J.F. Taylor, and S.K. Davis. 1994. Bovine microsatellite dinucleotide repeat polymorphisms at the TEXAN-1, TEXAN-2, TEXAN-3, TEXAN-4 and TEXAN-5 loci. Anim. Genet. 25: 201.

Hulme, D.J., J.P. Silk, J.M. Redwin, W. Barendse, and K.J. Beh. 1994. Ten polymorphic ovine microsatellites. Anim. Genet. 25: 434-435.

Hulme, D.J., A.J. Smith, J.P. Silk, J.M. Redwin, and K.J. Beh. 1995. Polymorphic sheep microsatellites at the McM2, McM131, McM135, McM136, McM140, McM200, McM214, McM373, McM505, McM507 and McM512 loci. Anim. Genet. 26: 369-370.

ISCNDA. 1990. International System for Cytogenetic Nomenclature of Domestic Animals (1989). Cytogenet. Cell. Genet. 53: 65-79.

Johnson, S.E., S.S. Moore, R. MacKinnon, D.J.S. Hetzel, and W. Barendse. 1995. The cosmid CSSM25 assigns syntenic group U2 to bovine chromosome 9 and is localized to ovine chromosome 8. Mamm. Genome 6: 529-531.

Jørgensen, C.B., B.A. Konfortov, W. Barendse, and J.R. Miller. 1995. Two polymorphic bovine microsatellite loci (AFR227 and AFR2215). Anim. Genet. 26: 132.

Kaback, D.B., V. Guacci, D. Barber, and J.W. Mahon. 1992. Chromosome size-dependent control of meiotic recombination. Science 256: 228-232.

Keele, J.W., J.E. Wray, D.W. Brehrens, G.A. Rohrer, S.L.F. Sunden, S.M. Kappes, M.D. Bishop, R.T. Stone, L.J. Alexander, and C.W. Beattie. 1994. A conceptual database model for genomic research. J. Computat. Biol. 1: 65-76.

Kemp, S.J. and A.J. Teale. 1991. Dinucleotide repeat polymorphism at the bovine locus FSHB. Anim. Genet. 22: 435 .

Kemp, S.J., O. Hishida, J. Wambugu, A. Rink, M.L. Longeri, R.Z. Ma, Y. Da, H.A. Lewin, W. Barendse, and A.J. Teale. 1995. A panel of polymorphic bovine, ovine and caprine microsatellite markers. Anim. Genet. 26: 299-306.

Kirkpatrick, B.W., M. Bradshaw, M.R. Dentine, and W. Barendse. 1995. Polymorphic bovine microsatellites UWCA25, UWCA26 and UWCA28. Anim. Genet. 26: 59-60.

Konfortov, B.A., C.B. Jørgensen, W. Barendse, and J.R. Miller. 1996. Five bovine polymorphic microsatellite markers (AF1-AF5). Anim. Genet. 27: 220-221.

Kossarek, L.M., W.M. Grosse, O. Finlay, X. Su, and R.A. McGraw. 1995a. Six bovine dinucleotide repeat polymorphisms: RM041, RM051, RM066, RM088, RM103 and RM113. Anim. Genet. 26: 55-56.

Kossarek, L.M., O. Finlay, W.M. Grosse, X. Su, S.M. Armitage, W. Barendse, and R.A. McGraw. 1995b. Five 


\section{KAPPES ET AL.}

bovine dinucleotide repeat polymorphisms: RM040, RM044, RM096, RM153 and RM179. Anim. Genet. 26: 57-58.

Lench, N.J., A. Norris, A. Bailey, A. Booth, and A.F. Markham. 1996. Vectorette PCR isolation of microsatellite repeat sequences using anchored dinucleotide repeat primers. Nucleic Acids Res. 24: 2190-2191.

Lincoln, S.E. and E.S. Lander. 1992. Systematic detection of errors in genetic linkage data. Genomics 14: 604-610.

Lord, E.A., J.M. Lumsden, K.G. Dodds, H.M. Henry, A.M. Crawford, H.A. Ansari, P.D. Pearce, D.W. Maher, R.T. Stone, S.M. Kappes, C.W. Beattie, and G.W. Montgomery. 1996. The linkage map of sheep Chromosome 6 compared with orthologous regions in other species. Mamm. Genome 7: 373-376.

Ma, R.Z., I. Russ, C. Park, D.W. Heyen, J.E. Beever, C.A. Green, and H.A. Lewin. 1996a. Isolation and characterization of 45 polymorphic microsatellites from the bovine genome. Anim. Genet. 27: 43-47.

Ma, R.Z., J.E. Beever, Y. Da, C.A. Green, I. Russ, C. Park, D.W. Heyen, R.E. Everts, S.R. Fischer, K.M. Overton, A.J. Teale, S.J. Kemp, H.C. Hines, G. Guérin, and H.A. Lewin. 1996b. A male linkage map of the cattle (Bos taurus) genome. J. Hered. 87: 261-271.

Masabanda, J., S.M. Kappes, T.P.L. Smith, C.W. Beattie, and R. Fries. 1996. Mapping of a linkage group to the last bovine chromosome (BTA27) without an assignment. Mamm. Genome 7: 229-230.

Matise, T.C., M. Perlin, and A. Chakravarti. 1994. Automated construction of genetic linkage maps (MultiMap): A human genome linkage map. Nature Genet. 6: 384-390.

McGraw, R.A., W.M. Grosse, S.M. Kappes, C.W. Beattie, and R.T. Stone. 1997. Thirty-four bovine microsatellite markers. Anim. Genet. (in press).

Mezzelani, A., Y. Zhang, L. Redaelli, B. Castiglioni, P. Leone, J.L. Williams, S. Solinas-Toldo, G. Wigger, R. Fries, and L. Ferretti. 1995. Chromosomal localization and molecular characterization of 53 cosmid-derived bovine micorsatellites. Mamm. Genome 6: 629-635.

Miller, S.A., D.D. Dykes, and H.F. Polesky. 1988. A simple salting out procedure for extracting DNA from human nucleated cells. Nucleic Acids Res. 16: 1215.

Montgomery, G.W., E.A. Lord, J.M. Penty, K.G. Dodds, T.E. Broad, L. Cambridge, S.L.F. Sunden, R.T. Stone, and A. Crawford. 1994. The Booroola fecundity (FecB) gene maps to sheep chromosome 6. Genomics 22: 148-153.

Moore, S.S., K. Byrne, K.T. Berger, W. Barendse, F. McCarthy, J.E. Womack, and D.J.S. Hetzel. 1994. Characterization of 65 bovine microsatellites. Mamm. Genome 5: 84-90.

Morkos, N.B.B., M.D. Grosz, and R.T. Stone. 1994.
Placement of $B o L A-D I B$ into a microsatellite-based linkage group. Anim. Genet. (Suppl. 2) 25: 55.

Morton, N.E. 1991. Parameters of the human genome. Proc. Natl. Acad. Sci. 88: 7474-7476.

Olsaker, I., S. Solinas-Toldo, and R. Fries. 1996. A highly polymorphic bovine dinucleotide repeat D19S4 (IOBT34) at chromosome 19q21. Anim. Genet. 27: 58-59.

Ott, J. 1977. Linkage analysis with misclassification at one locus. Clin. Genet. 12: 119-124.

Ott, J. and H. Donis-Keller. 1994. Statistical methods in genetic mapping. Genomics 22: 496-497.

Pierson, C.A., A.J. Ede, and A.M. Crawford. 1994. Ovine microsatellites at the OarHH30, OarHH51, OarVH54, OarCP88, OarCP93, OarCP134 loci. Anim. Genet. 25: 294-295.

Ponce de León, F.A., S. Ambady, G.A. Hawkins, S.M. Kappes, M.D. Bishop, J.M. Robl, and C.W. Beattie. 1996. Development of a bovine $\mathrm{X}$ chromosome linkage group and painting probes to assess cattle, sheep, and goat $\mathrm{X}$ chromosome segment homologies. Proc. Natl. Acad. Sci. 93: 3450-3454.

Popescu, C.P., S. Long, P. Riggs, J. Womack, S. Schmutz, R. Fries, and D.S. Gallagher. 1996. Standardization of cattle karyotype. Cytogenet. Cell Genet. 74: 259-261.

Rohrer, G.A., L.J. Alexander, J.W. Keele, T.P. Smith, and C.W. Beattie. 1994. A microsatellite linkage map of the porcine genome. Genetics 136: 231-245.

Rohrer, G.A., L.J. Alexander, Z. Hu, T.P.L. Smith, J.W. Keele, and C.W. Beattie. 1996. A comprehensive map of the porcine genome. Genome Res. 6: 371-391.

Schmutz, S.M., J.S. Moker, D.S. Gallagher, Jr., S.M. Kappes, and J.E. Womack. 1996. In situ hybridization mapping of LDHA and IGF2 to cattle chromosome 29. Mamm. Genome 7: 473.

Schwerin, M., S. Solinas-Toldo, A. Eggen, R. Brunner, H.M. Seyfert, and R. Fries. 1994. The bovine lactoferrin gene (LTF) maps to chromosome 22 and syntenic group U12. Mamm. Genome 5: 486-489.

Shalom, A., M.O. Mosig, W. Barendse, A. Friedmann, and M. Soller. 1994. Dinucleotide repeat polymorphism at the bovine HUJ246, HUJII77, HUJVI74, and HUJI75 loci. Anim. Genet. 25: 56.

Skow, L.C., J. Goy, and D. Honeycutt. 1994. Dinucleotide repeat polymorphism near a bovine MHC class I sequence. Anim. Genet. 24: 290.

Smith, A.J., D.J. Hulme, J.P. Silk, J.M. Redwin, and K.J. Beh. 1995. Thirteen polymorphic ovine microsatellites. Anim. Genet. 26: 277-278.

Smith, T.P.L., N.L. Lopez-Corrales, M.D. Grosz, C.W. Beattie, and S.M. Kappes. 1997. Anchoring of bovine chromosomes $4,6,7,10$, and 14 and linkage group 
telomeric ends via FISH analysis of lambda clones. Mamm. Genome (in press).

Solinas-Toldo, S., R. Fries, P. Steffen, H.L. Neibergs, W. Barendse, J.E. Womack, D.J.S. Hetzel, and G. Stranzinger. 1993. Physically mapped, cosmid-derived microsatellite markers as anchor loci on bovine chromosomes. Mamm. Genome 4: 720-727.

Solinas-Toldo, S., A. Mezzelani, G.A. Hawkins, M.D. Bishop, I. Olsaker, A. Mackinlay, L. Ferretti, and R. Fries. 1995. Combined Q-banding and fluorescence in situ hybridization for the identification of bovine chromosomes 1 to 7 . Cytogenet. Cell Genet. 69: 1-6.

Sonstegard, T.S., N.L. Lopez, S.M. Kappes, R.T. Stone, S. Ambady, F.A. Ponce de León, and C.W. Beattie. 1997a. An integrated genetic and physical map of the bovine $X$ chromosome. Mamm. Genome 8: 16-20.

Sonstegard, T.S., F.A. Ponce de León, C.W. Beattie, and S.M. Kappes. 1997b. A chromosome specific microdissected library increases marker density on bovine chromosome 1 . Genome Res. 7: 76-80.

Stone, R.T., J.C. Pulido, G.M. Duyk, S.M. Kappes, J.W. Keele, and C.W. Beattie. 1995. A small-insert bovine genomic library highly enriched for microsatellite repeat sequences. Mamm. Genome 6: 714-724.

Stone, R.T., S.M. Kappes, and C.W. Beattie. 1996a. Five polymorphic trinucleotide (CCA) bovine microsatellites. Anim. Genet. 27: 216.

Stone, R.T., S.M. Kappes, and C.W. Beattie. 1996b. The bovine homolog of the obese gene maps to Chromosome 4 . Mamm. Genome 7: 399-400.

Stone, R.T., S.M. Kappes, J.W. Keele, and C.W. Beattie. 1997. Characterization of 109 bovine microsatellites. Anim. Genet. (in press).

Sun, H.S., S. Whallon, A. Ponce de León, and B.W. Kirkpatrick. 1993. Development of polymorphic bovine microsatellite markers from a cosmid library. J. Anim. Sci. (Suppl.) 71: 100.

Sun, H.S., M.R. Dentine, W. Barendse, and B.W. Kirkpatrick. 1994. UWCA19 and UWCA20: Polymorphic bovine microsatellites. Anim. Genet. 25: 121.

Sun, H.S., W. Barendse, and B.W. Kirkpatrick. 1995. UWCA46, a polymorphic bovine microsatellite marker. $J$. Anim. Sci. 73: 1530.

Thieven, U., B. Harlizius, and D. Simon. 1995. Dinucleotide repeat polymorphism at the bovine HAUT1 and HAUT14 loci. Anim. Genet. 26: 123.

Threadgill, D.W. and J.E. Womack. 1990. Genomic analysis of the major milk protein genes. Nucleic Acids Res.

18: $6935-6942$.

Vaiman, D., D. Mercier, K. Moazami-Goudarzi, A. Eggen, R. Ciampolini, A. Lépingle, R. Velmala, J. Kaukinen, S.L.
Varvio, P. Martin, H. Levéziel, and G. Guérin. 1994a. A set of 99 cattle microsatellites: Characterization, synteny mapping, and polymorphism. Mamm. Genome 5: 288-297.

Vaiman, D., D. Mercier, A. Eggen, I. Bahri-Darwich, C. Grohs, E.P. Cribiu, G. Dolf, A. Oustry, G. Guérin, and H. Levéziel. 1994b. A genetic and physical map of bovine Chromosome 11. Mamm. Genome 5: 553-556.

Vaiman, D., A. Eggen, D. Mercier, I. Bahri-Darwich, C. Grohs, D. Bruneau, P. Laurent, B. Chaput, A. Oustry, G. Frelat, H. Levéziel, and E.P. Cribiu. 1995. A genetic and physical map of bovine chromosome 3. Anim. Genet. 26: $21-25$.

Vaiman, D., L. Schibler, F. Ourgeois, A. Oustry, Y. Amigues, and E.P. Cribiu. 1996. A genetic linkage map of the male goat genome. Genetics 144: 279-305.

Velmala, R., D. Vaiman, A. Virta, D. Mercier, and H. Levéziel. 1995. Polymorphic bovine microsatellites INRAMTT178, INRAMTT180 and INRAMTT183. Anim. Genet. 26: 201-213.

Weissig, H., A. Schildge, M.F. Hoylaerts, M. Iqbal, and J.L. Millan. 1993. Cloning and expression of the bovine intestinal alkaline phosphatase gene: Biochemical characterization of the recombinant enzyme. Biochem. J. 290: 503-508.

Williams, J.L., B.G. Urquhart, and W. Barendse. 1995. Three bovine chromosome 15 microsatellite markers. Anim. Genet. 26: 124 .

Yeh, C.C., J.F. Taylor, D.S. Gallagher, J.O. Sanders, J.W. Turner, and S.K. Davis. 1996. Genetic and physical mapping of the bovine X chromosome. Genomics 32: 245-252.

Yoo, J., R.T. Stone, S.M. Kappes, and C.W. Beattie. 1994. Linkage analysis of bovine interleukin 1 receptor types I and II (IL-1R I, II). Mamm. Genome 5: 820-821.

Yoo, J., S.M. Kappes, R.T. Stone, and C.W. Beattie. 1995. Linkage analysis assignment of bovine granulocyte colony stimulating factor receptor $(G-C S F R)$ to Chromosome 3. Mamm. Genome 6: 686-687.

Yoo, J., R.T. Stone, S.M. Kappes, S. Solinas Toldo, R. Fries, and C.W. Beattie. 1996. Genomic organization and chromosomal mapping of the bovine Fas/APO-1 gene. DNA Cell Biol. 15: 377-385.

Zahn, L.M. and D.J. Kwiatkowski. 1995. A 37-marker PCR-based genetic linkage map of human chromosome 9: Observations on mutations and positive interference. Genomics 28: 140-146.

Received October 18, 1996; accepted in revised form January 9, 1997. 


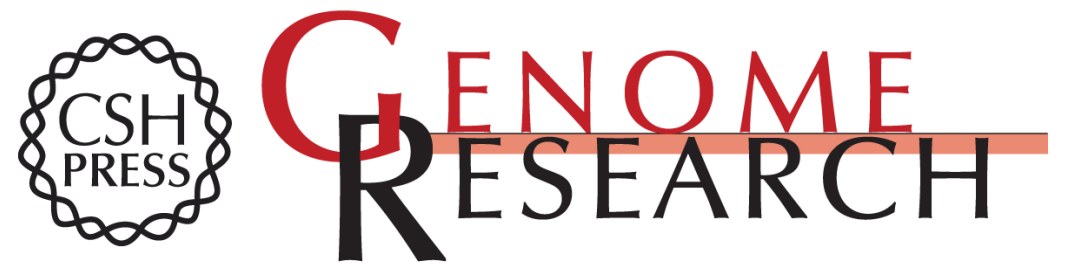

\section{A second-generation linkage map of the bovine genome.}

S M Kappes, J W Keele, R T Stone, et al.

Genome Res. 1997 7: 235-249

Access the most recent version at doi:10.1101/gr.7.3.235

\section{Supplemental http://genome.cshlp.org/content/suppl/2000/03/08/7.3.235.DC1 \\ Material}

References This article cites 101 articles, 15 of which can be accessed free at: http://genome.cshlp.org/content/7/3/235.full.html\#ref-list-1

\section{License}

Email Alerting Service

\section{Affordable, Accurate Sequencing.}

